\title{
Analysis of farmers' market power in the value chain of Arabica coffee in Lam Dong Province, Vietnam
}

\author{
Nguyen Thi Tuoi ${ }^{12^{*}}$, Nguyen Phu Son ${ }^{2}$, Pham Le Thong ${ }^{2}$ \\ ${ }^{1}$ Department of Agriculture and Forestry, Dalat University, Vietnam \\ ${ }^{2}$ Department of Economics, Can Tho University, Vietnam \\ *Corresponding author: tuoint@dlu.edu.vn
}

\section{ARTICLE INFO}

DOI: $10.46223 / \mathrm{HCMCOUJS}$. econ.en.12.1.1917.2022

Received: June $07^{\text {th }}, 2021$

Revised: July $10^{\text {th }}, 2021$

Accepted: July $22^{\text {nd }}, 2021$

Keywords:

arabica coffee farmers; lerner index; market power; value chain
ABSTRACT
The market that operates effectively will contribute to actors' profit and welfare in the coffee value chain conversely if the market is affected by imperfect problems. Suppose the value chain lacks market news, short-term storage, information for product and processing, quality check, and market power. In that case, implied chain actors' profit and welfare will not be reached. A new method can estimate market power by Lerner index through the stochastic cost frontier once the inputs data price is unavailable and the existence or non-existence of constant returns to scale. So this approach is applied to evaluate farmers' market power in the value chain of Arabica coffee in Lam Dong Province, Vietnam. Primary data were collected through interviews with 200 farmers Da Lat, Lac Duong, Lam Ha, and Don Duong of Lam Dong Province. The estimated results of the market power and Lerner rate are 0.001 . This index indicates that the local coffee market is perfect competition. So the coffee growers do not have market power. The RTS index of 0.56 (less than one) illustrates that farmers' Return To Scale (RTS) is decreased. Therefore, coffee farmers should link together to establish cooperative that increases market power in price negotiation and coffee consumption.

\section{Introduction}

Although Vietnam has nearly 623,000 hectares of coffee with more than 1.6 million tons and is the second coffee export globally. However, Vietnam's coffee exportation turnover is not high, estimating only nearly $8.8 \%$ of the agricultural sector's total (MARD, 2017). The reason is that Vietnam is principally exported in the raw materials form, the quality of green beans is not high, typically Robusta coffee. Lam Dong Province is the second largest coffee production area. The coffee area of Lam Dong was 143,285ha in 2010. After eight years, it increased to $22 \%$ and reached 174,766ha in 2018 (Lam Dong Statistical Office, 2019). The coffee area accounts for 60\% of the cultivated area of the province, of which the Arabica coffee region accounts for about $10 \%$ of the province's total. Besides, Lam Dong is famous for its high-quality Arabica coffee varieties, suitable climate, and soil advantages, especially in the Da Lat area. However, the coffee price of the households is volatile and low.

Farmers are the first and most important actors in the coffee value chain. However, the selling price of coffee farmers is low and volatile (Li \& Saghaian, 2014; T. N. Nguyen, Nguyen, \& Nguyen, 2017). Farmers sometimes have to sell their coffee at a lower price than the cost's 
production (Mehta \& Chavas, 2008). Because most coffee farmers have a small scale, so firms lose more time collecting coffee at their fields (G. N. T. Nguyen \& Sarker, 2018), therefore, most processors and exporters can not purchase agricultural products directly from farmers because they do not have enough personal sources, able practice, and technological support such as transportation, preservation, and dried (Do \& Nguyen, 2018; G. N. T. Nguyen \& Sarker, 2018; N. Q. Nguyen, Tran, Nguyen, \& Nguyen, 2018; Vo, Le, \& Nguyen, 2015). As a result, most coffee farmers sold immediately to middlemen (FAO, 2015; H. T. T. Nguyen \& Mai, 2017). These things have affected the ability to negotiate prices as well as the market power of coffee farmers.

The market concentration ratio of the head four firms CR4 or HHI is often used to estimate market power by previous studies. The estimate of this index is uncomplicated to complete, but when the above indicators measure market power, firm behavior is not modeled explicitly (Murphy, 2006). Lerner indicates a different ratio for evaluating market power, which can also be considered a measure of price appreciation (Lerner, 1934). The calculation Lerner ratio is necessary to calculate MC since this function is regularly not estimated except for constant returns to scale (Kumbhakar, Baardsen, \& Lien, 2012). Therefore, Wolfram (1999) calculated the MC function indirectly from estimating the total cost function. Another new empirical industrial organization method estimates Lerner indicates without directly estimating MC (Perloff \& Shen, 2012). However, the most significant limitation of both methods is the need for cost data such as input and output prices and constant efficiency conditions to scale. To overcome this limitation, a new approach by Kumbhakar et al. (2012) allows estimating market power once the inputs data price is unavailable and the existence or non-existence of constant returns to scale. Therefore, "Analysis of farmers' market power in the value chain of Arabica coffee in Lam Dong Province, Vietnam" is approached according to Kumbhakar et al. (2012) method.

\section{Method}

\subsection{Model of market power analysis}

As analyzed above, the stochastic frontier with Maximum Likelihood Estimation (MLE) has outstanding advantages (Kumbhakar et al., 2012). So some research have been used to examine market power in the food and agricultural sectors. For example, Cechura, Kroupová, and Hockmann (2015) use this approach to estimate the dairy industry's market power in the EU. Data were collected the period 2003 - 2012 from dairy processing firms from 24 EU countries. The results show that the dairy industry's market power in Europe is only shallow (mark-up $=0.121$ ). However, the mark-up index is also different from European countries. Some countries have tiny oligopolies, such as Lithuania, the United Kingdom, Bulgaria, and Sweden. In contrast, other countries have high oligopolies: Hungary, Austria, Portugal, and Finland. Silmilar, Koppenberg and Hirsch (2019) applied the stochastic cost frontier analysis to calculate oligopoly power in the European dairy processors from 2008 to 2017. The estimated results illustrate that Spain processors had the highest oligopoly power (0.053), Poland (0.030), and French only 0.0039.

Similar market power in the food industry is estimated by Lopez, Zheng, and Azzam (2015) between 1979 and 2009. It can be clearly seen that the market power of all the food industries is at least some oligopoly level, but modest. The average Lerner ratio is nearly 0.058 , significantly lower than NEIO methods. Lopez, He, and Azzam (2017) collected data from food processing enterprises in the US from 1990 to 2010 . The data also found that food processors have oligopoly power, by Lerner ratios equaling around 0.21. Most recently, Rahman et al. (2021) used a stochastic frontier analysis approach to analyze the mark-up of rice price in the value chain's rice. The data illustrate that the mark-up of wholesalers and millers are 0.29 and 0.33 , respectively; wholesalers and millers' Lerner ratios are 0.169 and 0.155 , each. 
The research applied the Kumbhakar et al. (2012) approach to evaluate farmers' market power in the value chain's Arabica coffee in Lam Dong Province. The method begins with an industry that has oligopoly power, where the price of output is greater than the marginal cost $(\mathrm{P}>\mathrm{MC})$ (Lopez et al., 2015). When $\mathrm{MC}=\mathrm{P}$, this is a competing market. In contrast, when $\mathrm{MC}<\mathrm{P}$ is not a competitive market. Set output is $\mathrm{Y}$, price of output is $\mathrm{P}$, and $\mathrm{C}$ is production cost. Beginning with:

$$
\mathrm{P} \geq \frac{\partial \mathrm{C}}{\partial \mathrm{Y}}=\mathrm{MC}
$$

Multiplying both terms of inequality (1) by the output/cost ratio (Y/C), we have:

$$
\frac{\mathrm{P} . \mathrm{Y}}{\mathrm{C}} \geq \frac{\partial \mathrm{C}}{\partial \mathrm{Y}} * \frac{\mathrm{Y}}{\mathrm{C}}=\frac{\partial \ln \mathrm{C}}{\partial \ln \mathrm{Y}}
$$

With $\mathrm{u}$ is a one-sided error and nonnegative factor. When adding $\mathrm{u}$ term, (2) can convert to (3); u expresses market failure. So Kumbhakar et al. (2012) method can estimate equation (3) applying the stochastic cost frontier function

$$
\frac{P . Y}{C}=\frac{\partial \ln C}{\partial \ln Y}+\mathrm{u}, \quad \mathrm{u} \geq 0
$$

where the total cost is $\mathrm{C}$, the revenue ratio/total cost is $\mathrm{P} . \mathrm{Y} / \mathrm{C}$, the scale's elasticity is $\partial \ln \mathrm{C} / \partial \ln \mathrm{Y}$, $\mathrm{u}$ is the term showing the mark-up, one-sided error, and nonnegative. Equation (3) is the mark-up model obtained from the condition of profit maximization. With the article, coffee farmers' inputs price data is available. So this study can use the translog cost function to estimate the elasticity of scale $(\partial \ln C / \partial \ln Y)$ as equation (4):

$$
\begin{gathered}
\ln C=\beta_{0}+\sum_{j=1}^{J} \beta_{j} \ln W_{j}+0,5 \sum_{j=1}^{J} \sum_{k=1}^{J} \beta_{j k} \ln W_{j} \ln W_{k}+\beta_{Y} \ln Y+0,5 \beta_{Y Y}(\ln Y)^{2}+ \\
\sum_{j=1}^{J} \beta_{j Y} \ln W_{j} \ln Y+\beta_{Y D} D_{P R}
\end{gathered}
$$

where the total cost is $\mathrm{C}$, the output is $\mathrm{Y}, \mathrm{W}$ expresses the input prices, $\beta$ are parameters, need value. The dummy variable is $D_{P R}$, and it will have a value of one if farmers process coffee. So $\partial \operatorname{lnC} / \partial \ln Y$ ratio can be presented as equation (5):

$$
\frac{\partial \ln C}{\partial \ln Y}=\beta_{Y}+\beta_{Y Y} \ln Y+\beta_{Y F} \ln W_{F}+\beta_{Y P} \ln W_{P}+\beta_{Y L} \ln W_{L}+\beta_{Y T} \ln W_{T}+\beta_{Y O} \ln W_{O}+\beta_{Y D} D_{P R}
$$

When replacing (5) with equation (3) and adding a statistical noise term (v), the equality condition will be rewritten as:

$$
\frac{P . Y}{C}=\beta_{Y}+\beta_{Y Y} \ln Y+\beta_{Y F} \ln W_{F}+\beta_{Y P} \ln W_{P}+\beta_{Y L} \ln W_{L}+\beta_{Y T} \ln W_{T}+\beta_{Y O} \ln W_{O}+\beta_{Y D} D_{P R}+u+v
$$

Set $\mathrm{PYC}$ ratio $=(\mathrm{P} . \mathrm{Y}) / \mathrm{C}, \mathrm{y}=\mathrm{Y} ; \mathrm{f}=\left(\mathrm{W}_{\mathrm{F}}\right) ; \mathrm{p}=\left(\mathrm{W}_{\mathrm{P}}\right) ; \mathrm{l}=\left(\mathrm{W}_{\mathrm{L}}\right) ; \mathrm{t}=\left(\mathrm{W}_{\mathrm{T}}\right) ; \mathrm{o}=\left(\mathrm{W}_{\mathrm{O}}\right)$; equation (6) can be rewritten as:

$P C Y$ ratio $=\beta_{Y}+\beta_{Y Y} \ln y+\beta_{Y F} \ln f+\beta_{Y P} \ln p+\beta_{Y L} \ln l+\beta_{Y T} \ln t+\beta_{Y O} \operatorname{lno}+\beta_{Y D} D_{P R}+u+v$

The $(u+v)$ is an error term, the same to the stochastic cost frontier function. With the twosided normal is $\mathrm{v}, \mathrm{v} \sim \mathrm{N}\left(0, \sigma_{\mathrm{v}}^{2}\right)$, and half-sided normal is $\mathrm{u}, \mathrm{u} \sim \mathrm{N}^{+}\left(0, \sigma_{\mathrm{u}}^{2}\right)$, equation (7) can be measured by the stochastic cost frontier with a maximum likelihood approach. u estimates the cost inefficiency in the stochastic frontier function; in contrast, $u$ is the mark-up in equation (7). Market power's degree and the mark-up have a relationship. $(\hat{\theta})$ is market power's degree, and it can be written as $\theta=(\mathrm{P}-\mathrm{MC}) / \mathrm{MC}$. The market power is presented as the mark-up function ( $\hat{\mathrm{u}})$ (Kumbhakar et al., 2012). So the market power $(\hat{\theta})$ can measure through the mark-up ( $\hat{u})$, as follows: 


$$
\widehat{\theta}=\frac{\widehat{u}}{\widehat{M C}}=\frac{\widehat{u}}{\frac{\partial \operatorname{lnC}}{\partial \ln Y}}
$$

The market power's degree of companies is expressed in equation (8). When $\frac{\partial \ln C}{\partial \ln Y}>1 ;<1$ or $=1$, RTS rate will decrease, increase, and constant, respectively. The RTS and Lerner ratio will be shown in equations (9) and (10), as follows:

$$
\begin{aligned}
& \widehat{\mathrm{RTS}}=\frac{1}{\frac{\partial}{\partial \operatorname{lnC}}} \\
& \widehat{\mathcal{L}}=\frac{\widehat{\theta}}{(1+\widehat{\theta})}
\end{aligned}
$$

\subsection{Data collection}

Questionnaire interviews are conducted from April to December 2020 to collect data. Primary data was collected through direct interviews with 200 coffee farmers in 04 areas in Lam Dong Province with large and concentrated coffee areas, including Da Lat 91, Lac Duong 71, Don Duong 24, and Lam Ha 15. The data was collected on coffee farmers' consumption and production in the crop year 2019/2020. The characteristics of the observed variables are presented in Table 1.

\begin{tabular}{|c|c|c|c|}
\hline Variable & Unit & Label & Source \\
\hline$(\mathrm{P} . \mathrm{Y}) / \mathrm{C}$ & & Revenue share & $\begin{array}{l}\text { Rahman et al. (2021); T. T. Nguyen, Nguyen, and } \\
\text { Pham (2021); Koppenberg and Hirsch (2019); } \\
\text { Lopez et al. (2017); Cechura et al. (2015); Lopez et } \\
\text { al. (2015); Kumbhakar et al. (2012). }\end{array}$ \\
\hline $\mathrm{Y}$ & tons/ha & Output of coffee & $\begin{array}{l}\text { Rahman et al. (2021); T. T. Nguyen et al. (2021); } \\
\text { Lopez et al. (2017); Cechura et al. (2015); Lopez } \\
\text { et al. (2015); Kumbhakar et al. (2012). }\end{array}$ \\
\hline $\mathrm{W}_{\mathrm{F}}$ & $\begin{array}{l}\text { Thousand } \\
\text { VND/kg }\end{array}$ & Price of fertilizers & The author suggested. \\
\hline $\mathrm{W}_{\mathrm{P}}$ & $\begin{array}{l}\text { Thousand } \\
\text { VND/liter }\end{array}$ & Price of pesticide & The author suggested. \\
\hline $\mathrm{W}_{\mathrm{L}}$ & $\begin{array}{l}\text { Thousand } \\
\text { VND/day }\end{array}$ & Salary of labor & $\begin{array}{l}\text { Rahman et al. (2021); T. T. Nguyen et al. (2021); } \\
\text { Lopez et al. (2017); Cechura et al. (2015); Lopez } \\
\text { et al. (2015); Kumbhakar et al. (2012). }\end{array}$ \\
\hline $\mathrm{W}_{\mathrm{T}}$ & $\begin{array}{l}\text { Thousand } \\
\text { VND/ton }\end{array}$ & Cost of transporting & Rahman et al. (2021); T. T. Nguyen et al. (2021). \\
\hline $\mathrm{W}_{\mathrm{O}}$ & $\begin{array}{l}\text { Thousand } \\
\text { VND/ton }\end{array}$ & Other input & $\begin{array}{l}\text { Rahman et al. (2021); T. T. Nguyen et al. (2021); } \\
\text { Lopez et al. (2017); Lopez et al. (2015); } \\
\text { Kumbhakar et al. (2012). }\end{array}$ \\
\hline $\mathrm{D}_{\mathrm{PR}}$ & & $\begin{array}{l}\text { This is a dummy } \\
\text { variable. It will } \\
\text { equal one if farmers } \\
\text { process coffee. }\end{array}$ & T. T. Nguyen et al. (2021). \\
\hline
\end{tabular}

\section{Table 1}

Explanation of the variables 


\section{Results and discussion}

\subsection{The characteristics of the observed variables}

Farmers are the first actors in the Arabica coffee value chain in Lam Dong Province. Their function is to cultivate coffee. After harvesting, farmers will sell coffee to traders, cooperatives, or processing companies in the form of coffee cherries and green beans. Factors in the production, processing and consumption of Arabica coffee by farmers in Lam Dong include fertilizers, pesticides, labor, transportation, other costs, and coffee output. Data on output, inputs, and prices were conducted by interviews with 200 coffee farmers in Lam Dong Province.

\section{Table 2}

The characteristics of the observed variables

\begin{tabular}{ccccccc}
\hline Variable & Unit & Obs & Mean & Std. Dev. & Min & Max \\
\hline$\left(\mathrm{P}^{*} \mathrm{Y}\right) / \mathrm{C}$ & & 200 & 0.021 & 0.013 & 0 & 0.044 \\
Y & tons/ha & 200 & 11.1 & 4.9 & 1.2 & 25 \\
WF & Thousand VND/kg & 200 & 11.7 & 1.4 & 8.0 & 14.0 \\
WP & Thousand VND/liter & 200 & 110.1 & 5.1 & 0 & 155.0 \\
WL & Thousand VND/day & 200 & 248.0 & 56.8 & 180.0 & 500.0 \\
WT & Thousand VND/ton & 200 & 95.0 & 120.8 & 0 & 500.0 \\
WO & Thousand VND/ton & 200 & 181.3 & 86.5 & 25.0 & 65.3 \\
\hline
\end{tabular}

Source: The reseacher's data analysis

In which WF is the fertilizer NPK price (thousands of VND/kg). The average fertilizer price is about 11.7 thousand VND/kg. However, households with economic conditions can buy better fertilizers for $14,000 \mathrm{VND} / \mathrm{kg}$. On the contrary, some farmers will buy cheaper manure or buy single fertilizer to mix by themselves $(8,000 \mathrm{VND} / \mathrm{kg})$. Pesticides for coffee have many types (fungicides, insecticides, herbicides) and many forms (powder, liquid) with numerous prices. Therefore, when calculating the price of pesticides, this study only chooses the price of 01 liters of herbicide for convenience in the calculation on average approximately $110,000 \mathrm{VND} / \mathrm{liter}$, as shown in Table 2.

There are also many differences between farmers regarding the use of pesticides in coffee farming. Some households do not use pesticides in coffee cultivation because they are aware of the harmful effects of pesticides on health and the environment. Since coffee prices have been low in recent years, farmers do not want to invest more. Labor wages (WL) are the salary that coffee farmers pay for hiring workers to do tasks such as harvesting, weeding, fertilizing, and spraying on their farms also vary widely. On average, a working day is about 250,000 VND. However, depending on how complex the job is, the labor cost also varies. For example, if weeding or fertilizing, the salary is lower, but the salary will be higher in the harvest season. Particularly, spraying pesticides is the highest work (500,000 VND) because of the high toxicity level. WT is the average transportation cost of farmers $(95,000 \mathrm{VND} /$ ton). This expense varies depending on the distance and transportation conditions of the farmer. There are farmers selling coffee right in the garden, and they do not have to bear this cost. Other expenditure inputs (WO) are packaging, depreciation, interest, and fuel (180,000 VND/ton). This cost is minimal, but it also varies among farmers.

Output (Y) in coffee farming of the household is the average quantity of coffee cherries 
and green beans/ha. $\mathrm{C}$ is the total cost of coffee production. It includes all costs associated with the production, processing, and consumption. Total revenue $\left(\mathrm{P}^{*} \mathrm{Y}\right)$ equals sales of coffee cherries and green beans. The ratio $\left(\mathrm{P}^{*} \mathrm{Y}\right) / \mathrm{C}$ is calculated as total sales divided by total production costs.

$\mathrm{C}$ is the total cost of coffee production. It includes all costs associated with the production, processing, and consumption. ( $\mathrm{P} * \mathrm{Y})$ is total revenue, including sales of green beans and coffee cherries. The $\left(\mathrm{P}^{*} \mathrm{Y}\right) / \mathrm{C}$ rate is computed as total revenue divided by production costs.

\subsection{Results calculation of the cost function}

Table 3 presents the parameters' results by measuring the stochastic cost frontier with the MLE method. The pesticides price, output, and other costs variables influence the $\mathrm{P}^{*} \mathrm{Y} / \mathrm{C}$ rate. Coffee farmers who did wet processing had a higher $\mathrm{P} * \mathrm{Y} / \mathrm{C}$ ratio than the non-processors by $0.87 \%$. Meanwhile, the price of fertilizer, labor, and transportation costs are not statistically significant.

\section{Table 3}

The estimated parameters' results of the cost function

\begin{tabular}{cccc}
\hline Parameters & Estimate & Standard error & P_value \\
\hline$\beta_{\mathrm{Y}}$ & 1.86 & 2.277924 & 0.413 \\
$\beta_{\mathrm{YY}}$ & 0.36 & 0.066406 & 0.000 \\
$\beta_{\mathrm{YF}}$ & 0.1621779 & 0.1743817 & 0.352 \\
$\beta_{\mathrm{YP}}$ & -0.0144282 & 0.0054764 & 0.008 \\
$\beta_{\mathrm{YL}}$ & 0.0018522 & 0.106123 & 0.986 \\
$\beta_{\mathrm{YT}}$ & -0.0032215 & 0.00373 & 0.388 \\
$\beta_{\mathrm{YO}}$ & -0.1971782 & 0.0463881 & 0.000 \\
$\beta_{\mathrm{YD}}$ & 0.8688541 & 0.1029619 & 0.000 \\
$\sigma_{\mathrm{v}}$ & -2.475819 & 0.1002093 & \\
$\sigma_{\mathrm{u}}$ & -11.72664 & 184.6236 & \\
\hline
\end{tabular}

Source: Data analysis result of the research

\subsection{Results of market power analysis}

$\hat{u}, \hat{\theta}, \mathrm{RTS}$, and $\mathcal{L}$ ratio express the Arabica coffee farmers' market power in Lam Dong Province, as displayed in Table 4. $\hat{\theta}$ rate of coffee farmers is 0.001 . which index is nearly zero, demonstrating that the farmers' coffee consumption market is perfectly competitive. So coffee farmers have no collusion or collusion among farmers to increase the selling price in the market. That also makes sense because most coffee farmers are small-scaled around $01-02$ ha (G. N. T. Nguyen \& Sarker, 2018; H. T. T. Nguyen \& Mai, 2017; T. N. Nguyen et al., 2017). Therefore, the output of each household is minimal compared to the total output of Lam Dong Province. Besides that, Vietnam's coffee price always depends on the price of the world (P. V. Nguyen \& To, 2014). Therefore, it is not easy for farmers to become coffee's price makers. This discussion is similar to analyzing coffee traders' $\mathcal{L}$ index results in Lam Dong Province (T. T. Nguyen et al., 2021).

Furthermore, processors' degree oligopoly in the instant coffee sector in India is also exercised (Deodhar \& Pandey, 2008). The measured processors' market power is around 12.8\%, proving that processing firms' monopoly power is minimal. So these instant coffee processors have operated in competitive markets instead of cooperating. 


\section{Table 4}

Estimates coffee farmers' market power

\begin{tabular}{|c|c|c|c|c|c|}
\hline Variable & Mean & Std.dev & 1st quartile & Median & 3rd quartile \\
\hline$\hat{u}$ & 0.0022674 & 0.0000101 & 0.0022622 & 0.0022672 & 0.002274 \\
\hline$\hat{\theta}$ & 0.0012749 & 0.0001575 & 0.0011798 & 0.0012625 & 0.001372 \\
\hline RTS & 0.5622696 & 0.0694083 & 0.5206572 & 0.5573054 & 0.6035118 \\
\hline $\mathcal{L}$ & 0.0012733 & 0.0001571 & 0.0011784 & 0.0012609 & 0.0013701 \\
\hline
\end{tabular}

Source: The reseacher's data analysis

The estimated results show that the RTS ratio is $0.56(<1)$. This indicator demonstrates a return to scale of households is decreased (Table 4). Therefore, when farmers invest in more inputs in production, they will not increase productivity at the same rate. The value is also actual because coffee production costs are increasing day by day: fertilizers, pesticides, and labor increase by $25-$ $30 \%$ (Tran, Le, Nguyen, Nguyen, \& Tran, 2017). While the price of coffee dropped to only 9,000 $\mathrm{VND} / \mathrm{kg}$ of coffee cherries, the yield of Arabica coffee decreased by more than $50 \%$ to only about 07 tons of coffee cherries/ha (Lam Dong Agricultural Extension Center, 2017). Like market power's degree, the $\mathcal{L}$ rate is too shallow, nearly $0.01 \%$. This number confirms that structure of the local coffee market is perfectly competitive.

Several studies have used the Lerner ratio in order to estimate market power of degree. This index shows that the $\mathcal{L}$ rate varies significantly in each period and country. There are essential differences in the L rate of coffee retailers between 1980 and 2005 in coffee-consuming countries (Gilbert, 2007). The $\mathcal{L}$ rate of the UK and Japan are the highest, 66.9\%, 59.0\%, respectively. In contrast, Netherlands, Germany, and France is lowest, 7.2\%, 0.0\%, and 0.0\%, respectively. At other times, the $\mathcal{L}$ ratio of a country is also different. For instance, coffee retailers' $L$ index in the USA from 1980 to 2005 was $14 \%$. For instance, coffee retailers' L index in the USA from 1980 to 2005 was $14 \%$ but declined to just $3.3 \%$ between 2001 and 2005 . Furthermore, coffee producers' L ratio from 2001 to 2005 too changed importance (Gilbert, 2007). $\mathcal{L}$ rate of Uganda, Brazil, and Tanzania is almost zero, while Indonesia, Vietnam, Columbia, and Côte d'Ivoire are much higher, $10.8 \%, 18.4 \%, 23.0 \%$, and $36.1 \%$, respectively. Tea exporters' oligopoly power has the same estimated result (Weerahewa, 2003).

\section{Conclusion and policy recommendation}

The analysis of farmers' market power in the value chain of Arabica coffee in Lam Dong shows that the market power and $\mathcal{L}$ index are equal to 0.001 , which indicates that the farmer's coffee market is perfectly competitive and that the farmer has no market power. An RTS of 0.56 $(<1)$ indicates a decrease in the size-effectiveness of households.

It is too difficult for farmers to increase income through improving market prices when coffee prices fall continuously and depend on world coffee prices. Therefore, increasing income for coffee farmers through improving market prices is complicated. However, farmers can increase their income by producing certified coffee (VietGAP, 4C, etc.) to improve quality and reduce costs; Harvest at the proper maturity to improve quality; focus on processing to create higher added value. Farmers should link up to form cooperatives to increase market power in purchasing inputs as well as consuming products instead of just producing separately on a small scale as at present.

This paper only focuses on analyzing farmers' market power. Therefore, it is necessary to study the market power of traders and companies to estimate the market power of each actor and hold the value chain of Arabica coffee in Lam Dong Province. 


\section{References}

Cechura, L., Kroupová, Z. Z., \& Hockmann, H. (2015). Market power in the European dairy industry. AGRIS Online Papers in Economics and Informatics, 7(2), 39-47.

Deodhar, S. Y., \& Pandey, V. (2008). Degree of instant competition! Estimation of market power in India's instant coffee market. Indian Economic Review, 43(2), 253-264.

Do, N. T., \& Nguyen, H. T. (2018). The participation of farmer households in the Ninh Thuan grape value chain. Journal of Science and Technology of Vietnam, 60(4),13-18.

Food and Agriculture Organization (FAO). (2015). Value chain analyses for Shan tea and Arabica coffee under climate change in the northern mountainous region of Viet Nam (Policy brief No.4). Rome, Italy: Economics and Policy Innovations for Climate-Smart Agriculture.

Food and Agriculture Organization (FAO). (2019). Area harvested and production quantity of coffee Vietnam. Retrieved March 10, 2021, from http://www.fao.org/faostat/en/\#data/QC

Gilbert, C. L. (2007). Have we been mugged? Market power in the world coffee industry (Department of Economics Working Papers, No. 0725). Trento, Italy: Department of Economics, University of Trento.

Koppenberg, M., \& Hirsch, S. (2019). Market power in EU dairy processing: Evidence from a stochastic frontier approach. Paper presented at the Agricultural \& Applied Economics Association 2019 Annual Meeting, Atlanta, GA.

Kumbhakar, S. C., Baardsen, S., \& Lien, G. (2012). A new method for estimating market power with an application to Norwegian sawmilling. Review of Industrial Organization, 40(2), 109-129. doi:10.1007/s11151-012-9339-7

Lam Dong Agricultural Extension Center. (2017). Arabica coffee in Da Lat decreased in yield. Retrieved March 10, 2021, from http://khuyennong.lamdong.gov.vn/thong-tin-nongnghiep/trong-trot/645-ca-pha-arabica-a-a-la-t-gia-m-n-ng-sua-t

Lam Dong Statistics Office. (2019). Lamdong statistical yearbook 2018. Hanoi, Vietnam: Statistical Publishing House.

Lerner, A. P. (1934). The concept of monopoly and the measurement of monopoly power. Review of Economic Studies, 1(3), 157-175.

Li, X. L., \& Saghaian, S. (2014). The presence of market power in the coffee market: The case of Colombian milds. Paper presented at the Agricultural \& Applied Economics Association's 2014 Annual Meeting, Minneapolis Minnesota, Portal.

Lopez, R. A., He, X., \& Azzam, A. (2017). Stochastic frontier estimation of market power in the food industries. Journal of Agricultural Economics,69(1), 3-17. doi:10.1111/14779552.12219

Lopez, R. A., Zheng, H., \& Azzam, A. (2015). Oligopoly power in the food industries revisited: A stochastic frontier approach. Paper presented at the Agricultural and Applied Economics Association's 2015 AAEA \& WAEA Joint Annual Meetings, San Francisco, CA.

Mehta, A., \& Chavas, J. P. (2008). Responding to the coffee crisis: What can we learn from price dynamics? Journal of Development Economics, 85(2), 282-311. doi:10.1016/j.jdeveco.2006.07.006 
Ministry of Agriculture and Rural Development (MARD). (2017). Reported results of implementing the December 2017 plan for the agriculture and rural development sector. Retrieved March 26, 2021, from https://www.mard.gov.vn/ThongKe/Lists/ BaoCaoThongKe/Attachments/132/Baocao_T12_2017.pdf

Murphy, S. (2006). Concentrated market power and agricultural trade. Berlin, Germany: Concentrated Market Power and Agricultural Trade - Sophia Murphy.

Nguyen, G. N. T., \& Sarker, T. (2018). Sustainable coffee supply chain management: A case study in Buon Me Thuot City, Daklak, Vietnam. International Journal of Corporate Social Responsibility, 3(1), 1-17. doi:10.1186/s40991-017-0024-х

Nguyen, H. T. T., \& Mai, D. T. T. (2017). Describing the coffee value chain in the Central Highlands of Vietnam. Australasian Agribusiness Perspectives, 20(2017), 78-89.

Nguyen, N. Q., Tran, C. T. D., Nguyen, T. T. K., \& Nguyen, R. V. (2018). Value chain analysis of Ha Chau mulberry products in Phong Dien district, Can Tho City. Science Journal of Can Tho University, 54(4) 220-228.

Nguyen, P. V., \& To, H. T. K. (2014). Cointegration test for Vietnam's coffee export price and world coffee price over the period 2008-2014. Ho Chi Minh City Open University Journal of Science, 9(3), 80-86.

Nguyen, T. N., Nguyen, T. T., \& Nguyen, C. T. (2017). Risk analysis in coffee production of farm households in Dak Lak Province. Vietnam Journal of Agricultural Sciences, 15(2), 243-252.

Nguyen, T. T., Nguyen, S. P., \& Pham, T. L. (2021). Analysis of farmers' market power in the Arabica coff ee value chain in Lam Dong Province, Vietnam. International Journal of Economics and Financial Research, 7(3), 102-108. doi:10.32861/ijefr.73.102.108

Perloff, J. M., \& Shen, E. Z. (2012). Collinearity in linear structural models of market power. Review of Industrial Organization, 40(2), 131-138. doi:10.1007/s11151-012-9336-X

Rahman, M. C., Pede, V., Balie, J., Pabuayon, I. M., Yorobe, J. M., \& Mohanty, S. (2021). Assessing the market power of millers and wholesalers in the Bangladesh rice sector. Journal of Agribusiness in Developing and Emerging Economies, 11(3), 280-295. doi:10.1108/JADEE-04-2018-0053

Tran, N. H., Le, V., Nguyen, L. D., Nguyen, T. A., \& Tran, L. D. (2017). Optimizing production inputs of coffee production in Lam Ha district, Lam Dong Province. Van Hien University Journal of Science, 5(3), 63-73.

Vo, T. N., Le, L. N. Q., \& Nguyen, P. T. K. (2015). The situation of the rice supply chain in the Mekong River Delta. Journal of Science and Technology Development, 18(2), 121-136.

Weerahewa, J. (2003). Estimating market power of tea processing sector. Sri Lankan Journal of Agricultural Economics, 5(1), 69-82.

Wolfram, C. D. (1999). Measuring duopoly power in the British electricity spot market. American Economic Review, 89(4), 805-826.

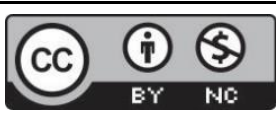

Creative Commons Attribution-NonCommercial 4.0 International License. 